\title{
Fibrous Polyp
}

National Cancer Institute

\section{Source}

National Cancer Institute. Fibrous Polyp. NCI Thesaurus. Code C8311.

A polyp with a fibrous core. 